CORRECTION

\title{
Correction to: Enteric neuroimmune interactions coordinate intestinal responses in health and disease
}

\author{
Haozhe Wang, Jaime P. P. Foong, Nicola L. Harris and Joel C. Bornstein
}

(c) The Author(s) 2021

Mucosal Immunology (2022) 15:188; https://doi.org/10.1038/s41385-021-00459-7

Correction to: Mucosal Immunology https://doi.org/10.1038/ s41385-021-00443-1, published online 1 September 2021

The original version of this article unfortunately was missing requisite credit lines in Figs. 1-4. Images presented in Fig. 1 adapted from Foong JPP, Hung LY, Poon S, Savidge TC, Bornstein JC. Early life interaction between the microbiota and the enteric nervous system. American Journal of Physiology-Gastrointestinal and Liver Physiology 2020;319(5):G541-G548, and modified by the authors. Images presented in Figs. 2-4 adapted from Servier Medical Art (http://smart.servier.com/) and modified by the authors under the following terms: Creative Commons Attribution 3.0 Unported (CC BY 3.0). The original article has been corrected. (c) (i) Open Access This article is licensed under a Creative Commons Attribution 4.0 International License, which permits use, sharing, adaptation, distribution and reproduction in any medium or format, as long as you give appropriate credit to the original author(s) and the source, provide a link to the Creative Commons license, and indicate if changes were made. The images or other third party material in this article are included in the article's Creative Commons license, unless indicated otherwise in a credit line to the material. If material is not included in the article's Creative Commons license and your intended use is not permitted by statutory regulation or exceeds the permitted use, you will need to obtain permission directly from the copyright holder. To view a copy of this license, visit http://creativecommons. org/licenses/by/4.0/.

() The Author(s) 2021 